\title{
Effect of Potassium Fertilizer Split Applications together with Straw on Optimum Level in Leaf and Stem of Rice
}

\author{
E. Pavithira ${ }^{1}$, D. N. Sirisena ${ }^{2}$ and H. M. S. K. Herath ${ }^{1}$ \\ Received: $9^{\text {th }}$ June 2016 / Accepted: $5^{\text {th }}$ October 2016
}

\begin{abstract}
Effect of long term $K$ fertilizer application together with rice straw on optimum $K$ level in leaf and stem of rice plants was evaluated in a field experiment. No K fertilizer (T1), rice straw only (T2); $20 \mathrm{~kg} \mathrm{~K}_{2} \mathrm{O} \mathrm{ha} \mathrm{h}^{-1}$ of $\mathrm{K}$ (both at basal dressing and panicle initiation) with rice straw (T3), 20

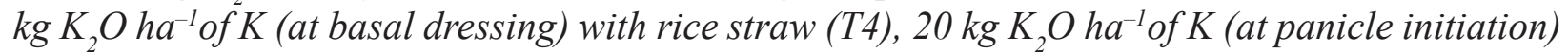
with rice straw (T5), and $20 \mathrm{~kg} \mathrm{~K}_{2} \mathrm{O}$ ha $\mathrm{a}^{-1}$ of $\mathrm{K}$ (both at basal dressing and panicle initiation) (T6) were applied. Rice straw was amended at the rate of $5 \mathrm{th} \mathrm{h}^{-1}$. Soil samples were analysed for exchangeable $K$ and non-exchangeable $K$ during the growing season and plant samples were analysed for $K$ content in leaf and stem at maturity (12 weeks after planting). At harvesting, total grain yield and number of panicles were recorded. Soil and plant $K$ contents under no $K$ fertilizer (T1) were significantly lower $(P<0.05)$ throughout the cultivation period compared to all other treatments. However, shoot dry matter, number of panicles, and grain yield were not significantly different $(P>0.05)$ among treatments. All $K$ fertilizer applied plots depicted higher $K$ content in leaves and stem of rice plants, compared to the no K fertilizer treated plots, irrespective of straw application. The highest exchangeable $K$ and non-exchangeable $K$ contents were recorded in the treatment received with $\mathrm{K}$ fertilizer at the rate of $20 \mathrm{~kg} \mathrm{~K}_{2} \mathrm{O} \mathrm{ha} \mathrm{h}^{-1}$ (at basal dressing and panicle initiation) with rice straw, T3). When consider plant $K$ uptake in relation to the non-exchangeable $K$ there was a positive relationship irrespective of the type of treatment and the number of weeks after planting. According to these results it can be concluded that to maintain optimum $K$ content $(1.5 \%)$ in leaf and stem of rice plant, it is needed to apply K fertilizer together with rice straw.
\end{abstract}

Keywords: Chemical fertilizer, panicle initiation, potassium, rice straw, rice yield

\section{INTRODUCTION}

Rice is the single most crop that occupies 34 $\%$ of the total cultivated lands in Sri Lanka (Department of Agriculture, 2010). Annual per capita consumption of rice is $100 \mathrm{~kg}$, and at present, national average rice yield is $4.5 \mathrm{t} \mathrm{ha}^{-1}$. Given the nutritional and high caloric value, rice has become the staple food in the country.

In rice production, still the gap between potential yield and actual yield is high in most of the rice growing areas. This variation is given by the factors such as ecological factors, bio-physical factors, management practices, and cultural and socio-economic conditions. However, there is a possibility that the gap can be minimized through proper management of soil, fertilizer, pest, weed, and water (Food and Agriculture Organization of the United Nations, 2004). In fact, fertilizer management is the key that affects on potential yield in paddy. According to Sirisena et al. (2001), fertilizer use efficiency of rice plant exists between $25-30 \%$ and thus, it implies how fertilizer application wastes a large amount of money, on one hand, and how it contributes to the environmental pollution significantly, on the other hand.

Nitrogen $(\mathrm{N})$, phosphorous $(\mathrm{P})$, and potassium

\footnotetext{
1 Department of Export Agriculture, Faculty of Animal Science and Export Agriculture, Uva Wellassa University, Passara Road, 90000, Badulla, Sri Lanka.

2 Rice Research and Development Institute, Batalagoda, 60500, Ibbagamuwa, Sri Lanka.
} 
$(\mathrm{K})$ are the three major nutrients required for rice plant and among them $\mathrm{K}$ plays a major role in growth and development (Doberman and Fairhurst, 2000). Potassium involves in essential functions such as osmo-regulation, enzyme activation, regulation of cellular cationanion balance, regulation of transpiration by stomata, and the transport of assimilates. In addition to the normal function, optimum $\mathrm{K}$ nutrition increases the number of spikelets per panicle, percentage of filled grains, and 1000 grain-weight in rice. It also gives a strength to the rice plant and helps stand firm against strong winds by improving rigidity of pseudo stems and stalks. This is important to reduce lodging. Overall, all these affect on the quality of crop produce. Conversely, $\mathrm{K}$ deficient plants are susceptible to plant diseases such as bacterial leaf blight, sheath blight, brown spots, and seed spots (Doberman and Fairhurst, 2000). Potassium deficiency symptoms in rice plant are often not detectable because its symptoms are not easy to be recognised as those of $\mathrm{N}$ and $\mathrm{P}$ deficiencies. Also, the symptoms tend to appear during the later growth stages. Stunted plants with early senescence leaves and wilting are recognised as some of the $\mathrm{K}$ deficiency symptoms. K deficient plants are susceptible to lodging and produce large number of sterile and unfilled grains and have an unhealthy root system (Doberman and Fairhurst, 2000). Therefore, more attention should be given to the $\mathrm{K}$ nutrition in rice in order to increase the rice production.

Use of organic matter to meet the nutrient requirement of crops would be an inevitable practice in years to come, particularly for resource poor farmers (Palm et al., 1997). However, the use of organic manures alone may not be effective to meet the enormous nutrient requirements of present day high yielding cultivars. Therefore, an integrated nutrient management in which both organic manures and chemical fertilizers are used simultaneously is suggested as the most effective method to maintain a healthy and sustainable soil system while increasing crop productivity. There are many organic sources, which can be used as organic amendments; for example, crop residues, compost, animal manure and green manure (Bandara et al., 2009). In this context, rice straw is the only organic material, which is available in significant quantities to most of the rice farmers. Therefore, rice straw can be used as a substitute for $\mathrm{K}$ fertilizer. It contains about $0.6 \% \mathrm{~N}, 0.1 \%$ each of P and S, $1.5 \% \mathrm{~K}, 5 \%$ $\mathrm{Si}$, and $40 \% \mathrm{C}$ (Amarasiri and Wickramasighe, 1988). Incorporation of rice straw in to soil returns most of the nutrients mainly $\mathrm{K}$ and more importantly it reduces $\mathrm{K}$ leaching from the soil.

Of the major nutrient elements, $\mathrm{K}$ is usually the most abundant in soils (Reitemeier, 1951). Adsorption of K varies from soil to soil. Soil $\mathrm{K}$ exists in four forms in soils, i.e. (i) solution $\mathrm{K}$, (ii) exchangeable $\mathrm{K}$, (iii) fixed or nonexchangeable $\mathrm{K}$, and (iv) structural or mineral $\mathrm{K}$. Bulk of total soil $\mathrm{K}$ is in the mineral fraction (Sparks and Huang, 1985). Among those four types, exchangeable $\mathrm{K}$ is taken as an indicator in determining the $\mathrm{K}$ supplying capacity of paddy soils for many years. The exchangeable $\mathrm{K}$ in soils varies from $31-331 \mathrm{mg} \mathrm{kg}^{-1}$ in low country dry and intermediate zones, $51-175$ $\mathrm{mg} \mathrm{kg}^{-1}$ in mid country wet zone, and $27-94$ $\mathrm{mg} \mathrm{kg}^{-1}$ in low country wet zone (Weerasinghe, 1991). When amount of exchangeable $K$ in soil is depleted, there is a possibility to replenish non-exchangeable $\mathrm{K}$ to exchangeable $\mathrm{K}$. Therefore, this has to be evaluated in details with respect to the changes of soil $\mathrm{K}$ with the application of $\mathrm{K}$ fertilizer and rice straw. The present study assessed the significance of split application of $\mathrm{K}$ fertilizers together with rice straw on optimum level of $\mathrm{K}$ in the rice leaf and stem.

\section{MATERIALS AND METHODS}

The study was conducted at the Rice Research and Development Institute (RRDI), Batalagoda, Kurunegala district, Sri Lanka located in the Low Country Intermediate Zone, IL1 agro ecological 
region $\left(80^{\circ} 81^{\prime} \mathrm{E}\right.$ and $7^{\circ} \mathrm{N} 8^{\prime} \mathrm{N}, 65 \mathrm{~m}$ above sea level). The major soil group is Kurunegala soil series (Psammentich Apludult), which belongs to the great soil group of imperfectly drained Red Yellow Podzolic soil (RYP) coming under the soil order Ultisol. Basic physico-chemical properties of the soil are given in Table 01 .

Different K fertilizer management practices have been carried out for a long period ( $7^{\text {th }}$ season) in separate field blocks at RRDI. The experiment comprised of six treatments as follows: (i) No $\mathrm{K}$ fertilizer (T1); (ii) rice straw only (T2); (iii) $20 \mathrm{~kg} \mathrm{~K}_{2} \mathrm{O} \mathrm{ha}^{-1}$ of $\mathrm{K}$ (both at basal dressing and panicle initiation) with rice straw (T3); (iv) 20 $\mathrm{kg} \mathrm{K}_{2} \mathrm{O} \mathrm{ha}{ }^{-1}$ of $\mathrm{K}$ (at basal dressing) with rice straw (T4); (v) $20 \mathrm{~kg} \mathrm{~K}_{2} \mathrm{O}^{-1}$ of $\mathrm{K}$ (at panicle initiation) with rice straw (T5); (vi) $20 \mathrm{~kg} \mathrm{~K}_{2} \mathrm{O}$ $\mathrm{ha}^{-1}$ of $\mathrm{K}$ (both at basal dressing and panicle initiation) (T6) and arranged in a Randomized Complete Block Design (RCBD) with four replicates $(n=4)$. Rice straw was incorporated at the rate of $5 \mathrm{t} \mathrm{ha}^{-1}$, at two weeks after the first ploughing. $40 \mathrm{~kg} \mathrm{~K}_{2} \mathrm{O} \mathrm{ha} \mathrm{h}^{-1}$ of $\mathrm{K}$ fertilizer was applied as split in to $20 \mathrm{~kg} \mathrm{~K}_{2} \mathrm{O} \mathrm{ha} \mathrm{ha}^{-1}$ of $\mathrm{K}$ at basal and $20 \mathrm{~kg} \mathrm{~K} O \mathrm{ha}^{-1}$ of $\mathrm{K}$ at panicle initiation stage ( 6 weeks after planting). The most common $\mathrm{K}$ fertilizer is muriate of potash (MOP), which contains about $50 \% \mathrm{~K}$ (60\% $\mathrm{K}_{2} \mathrm{O}$ ) in the form of $\mathrm{KCl}$.

Soil samples were collected randomly from each plot up to $10-15 \mathrm{~cm}$ depth using a soil auger to analyse exchangeable $\mathrm{K}$ and nonexchangeable $\mathrm{K}$ : before planting (initial soil sampling) and planting to maturity at weekly interval. Exchangeable $\mathrm{K}$ content in soil was determined using $1 \mathrm{M}$ ammonium acetate ( $\mathrm{NH}_{4} \mathrm{OAc}$ ) extractant following the method descried by Perkin-Elmer (1994). Nonexchangeable $\mathrm{K}$ content in soil was analysed as described by Pratt (1965) using Atomic
Absorption Spectrophotometer (AAS) with an extraction of boiling $\mathrm{HNO}_{3}$. Plant samples were taken at $100 \%$ flowering stage to determine plant dry matter and potassium uptake. Plant $\mathrm{K}$ analysis was carried out according to the wet digestion method (Anon, 1956). Number of tillers per hill and the plant height were measured at the maximum tillering stage (45 days after planting). At $85 \%$ maturity (12 week after planting), the total grain yield and a number of panicles were recorded.

The statistical differences between the treatments under study were determined by analysis of variance (ANOVA) using Statistical Analysis System (SAS) software package. Mean separation was undertaken using Duncan's New Multiple Range Test at $P=0.05$.

\section{RESULTS AND DISCUSSION}

\section{Soil exchangeable Potassium content}

Table 02 shows the changes in exchangeable $\mathrm{K}$ content of soil resulted having added $\mathrm{K}$ fertilizer and rice straw. Accordingly, the exchangeable $\mathrm{K}$ content of soil was significantly increased $(\mathrm{P}<0.05)$ with addition of $\mathrm{K}$ fertilizer and rice straw. The initial exchangeable $\mathrm{K}$ content in this study site was $28.5 \mathrm{mg} \mathrm{kg}^{-1}$. It is comparable with the findings of Panabokke and Nagarajah (1964) in which exchangeable $\mathrm{K}$ content in Kurunegala series was $<39 \mathrm{mg} \mathrm{kg}{ }^{-1}$. After rice straw application (after two weeks), the exchangeable $\mathrm{K}$ content in rice straw treated plots were recorded as $40.4 \mathrm{mg} \mathrm{kg}^{-1}$ while it was only $30.4 \mathrm{mg} \mathrm{kg}^{-1}$ in non-treated plots. Amarasiri and Wickramasingha (1988) have reported that rice straw contains $1.3-2.0 \%$ of $\mathrm{K}$. Thus, it is expected that this $\mathrm{K}$ may have affected on the above increase. 
Table 01: Basic physico-chemical properties of the soil in Kurunegala series as adapted from Mapa et al., (2005).

\begin{tabular}{|c|c|c|c|c|c|c|c|c|c|c|c|}
\hline \multirow{2}{*}{ Horizon } & \multirow{2}{*}{$\begin{array}{l}\text { Depth } \\
(\mathrm{cm})\end{array}$} & \multirow{2}{*}{$\begin{array}{l}\text { Sand } \\
(\%)\end{array}$} & \multirow{2}{*}{$\begin{array}{l}\text { Silt } \\
(\%)\end{array}$} & \multirow{2}{*}{$\begin{array}{l}\text { Clay } \\
(\%)\end{array}$} & \multirow{2}{*}{$\mathrm{pH}$} & \multirow{2}{*}{$\begin{array}{c}\mathrm{CEC} \\
\mathrm{c} \mathrm{mol} \mathrm{kg}^{-1}\end{array}$} & \multicolumn{5}{|c|}{ Exchangeable mg kg-1 } \\
\hline & & & & & & & $\mathrm{K}$ & $P$ & $\mathrm{Ca}$ & $\mathrm{Mg}$ & $\mathrm{Na}$ \\
\hline Surfa & $0-30$ & 84 & 8 & 8 & 52 & 6.5 & 39 & 7 & 600 & 84 & 46 \\
\hline Subsoil & $30-94$ & 54.5 & 13.5 & 32 & 5.3 & 28 & 39 & 4 & 900 & 240 & 103.5 \\
\hline
\end{tabular}

$\mathrm{n}=3$

Table 02: Mean values of soil exchangeable $\mathrm{K}$.

\begin{tabular}{cccccc}
\hline Treatments & Initial & 2 WAP & 4 WAP & 6 WAP & 8 WAP \\
\hline T1 & $19.3^{\mathrm{c}}$ & $25.4^{\mathrm{d}}$ & $30.4^{\mathrm{c}}$ & $35.9^{\mathrm{c}}$ & $31.7^{\mathrm{c}}$ \\
T2 & $25.7^{\mathrm{bc}}$ & $33.4^{\mathrm{c}}$ & $35.1^{\mathrm{bc}}$ & $39.8^{\mathrm{c}}$ & $37.4^{\mathrm{bc}}$ \\
T3 & $34.5^{\mathrm{a}}$ & $46.3^{\mathrm{a}}$ & $48.2^{\mathrm{a}}$ & $58.9^{\mathrm{a}}$ & $51.7^{\mathrm{a}}$ \\
T4 & $32.4^{\mathrm{ab}}$ & $42.9^{\mathrm{ab}}$ & $46.9^{\mathrm{a}}$ & $50.8^{\mathrm{ab}}$ & $47.9^{\mathrm{a}}$ \\
T5 & $29.5^{\mathrm{ab}}$ & $38.7^{\mathrm{abc}}$ & $39.9^{\mathrm{ab}}$ & $45.9^{\mathrm{bc}}$ & $42.9^{\mathrm{ab}}$ \\
T6 & $29.4^{\mathrm{ab}}$ & $35.3^{\mathrm{bc}}$ & $35.7^{\mathrm{bc}}$ & $40.4^{\mathrm{c}}$ & $36.4^{\mathrm{bc}}$ \\
\hline
\end{tabular}

WAP - weeks after planting

Means followed by the same letter at the same column are not significantly different by Duncans post-hoc test at $\mathrm{P}<0.05$.

As per the results in Table 02 it is revealed that two weeks after planting, there was a significant difference $(\mathrm{P}<0.05)$ between the treatments. The highest soil exchangeable $\mathrm{K}$ content was recorded in T3 plots, which were treated with rice straw and $\mathrm{K}$ fertilizer (basal $\mathrm{K}+$ panicle initiation K). Amarasiri and Wickramasingha (1988) showed that incorporation of rice straw into the soil returns most of the nutrients mainly $\mathrm{K}$ and reduces $\mathrm{K}$ leaching from the soil. Therefore, paddy straw can be used as a source of K together with MOP fertilizer. Thus, the amount of recommended potash fertilizers (MOP) can be replaced by straw to a significant level in paddy cultivation. Soil exchangeable K content in control plots were significantly lower $(\mathrm{P}<0.05)$, throughout the cultivation period, than that of the $\mathrm{K}$ fertilizer or rice straw amended plots. A minor variation in exchangeable $\mathrm{K}$ content in control plots between the replicates could be observed. This may be due to $\mathrm{K}$ in rice stubbles and irrigation water. Supply of $\mathrm{K}$ through irrigation water is confirmed by the findings of Liyanage et al. (1989). They report that $\mathrm{K}$ in irrigation water could be the only source for increasing $\mathrm{K}$ reserves in non-treated plots.

\section{Soil non-exchangeable potassium content}

Table 03 shows the mean values of the soil nonexchangeable $\mathrm{K}$ content in the study site having treated under different conditions, as described above. There was a significant difference $(\mathrm{P}<0.05)$ in initial soil $\mathrm{K}$ (Table 3 ). The highest initial soil non-exchangeable $\mathrm{K}$ content was recorded as $160.2 \mathrm{mg} \mathrm{kg}^{-1}$ in $\mathrm{T} 3$ plots whereas the lowest was recorded in the untreated plots (116.8 $\mathrm{mg} \mathrm{kg}^{-1}$ ). This may be due to long term application of rice straw and chemical $\mathrm{K}$ fertilizer. 
Table 03: Mean values of soil non-exchangeable $\mathrm{K}$.

\begin{tabular}{cccccc}
\hline Treatments & Initial & 2 WAP & 4 WAP & 6 WAP & 8 WAP \\
\hline T1 & $116.8^{\mathrm{b}}$ & $141.8^{\mathrm{b}}$ & $206.7^{\mathrm{a}}$ & $219.1^{\mathrm{a}}$ & $197.9^{\mathrm{a}}$ \\
T2 & $131.1^{\mathrm{ab}}$ & $172.3^{\mathrm{a}}$ & $176.8^{\mathrm{a}}$ & $233.6^{\mathrm{a}}$ & $204.3^{\mathrm{a}}$ \\
T3 & $160.2^{\mathrm{a}}$ & $211.3^{\mathrm{a}}$ & $260.7^{\mathrm{a}}$ & $319.1^{\mathrm{a}}$ & $246.3^{\mathrm{a}}$ \\
T4 & $158.8^{\mathrm{ab}}$ & $204.9^{\mathrm{ab}}$ & $188.5^{\mathrm{a}}$ & $243.9^{\mathrm{a}}$ & $222.1^{\mathrm{a}}$ \\
T5 & $132.5^{\mathrm{ab}}$ & $143.7^{\mathrm{b}}$ & $184.4^{\mathrm{a}}$ & $236.7^{\mathrm{a}}$ & $213.3^{\mathrm{a}}$ \\
T6 & $126.8^{\mathrm{ab}}$ & $137.9^{\mathrm{ab}}$ & $162.5^{\mathrm{a}}$ & $226.5^{\mathrm{a}}$ & $200.8^{\mathrm{a}}$ \\
\hline
\end{tabular}

WAP - weeks after planting

Means followed by the same letter at the same column are not significantly different by Duncans post-hoc test at $\mathrm{P}<0.05$.

After rice straw application (after two weeks), soil non-exchangeable $\mathrm{K}$ content in rice straw treated plots were recorded as $183.0 \mathrm{mg} \mathrm{kg}^{-1}$ while it was $139.9 \mathrm{mg} \mathrm{kg}^{-1}$ in non-treated plots. It implies that straw can be a good source of $\mathrm{K}$ even in the non-exchangeable $\mathrm{K}$ pool. Soil non-exchangeable $\mathrm{K}$ content in control plots was significantly lower $(\mathrm{P}<0.05)$, throughout the cultivation period, compared to $\mathrm{K}$ fertilizer or rice straw treated plots.

According to the results, two weeks after planting, there was a significant difference $(\mathrm{P}<0.05)$ between the treatments; both rice straw and $\mathrm{K}$ fertilizer treated plots (T3) were recorded the highest soil non-exchangeable $\mathrm{K}$ content. However, thereafter, no significant difference was recorded $(\mathrm{P}>0.05)$ up to the eighth week in non-exchangeable pool. But, there was an increasing trend among treatments up to the sixth week. Higher amount of nonexchangeable $\mathrm{K}$ content was obtained in rice straw and $\mathrm{K}$ fertilizer treated plots compared to non-treated plots. Given the increase of nonexchangeable $\mathrm{K}$ content in the amended plots it is apparent that allocation of $\mathrm{K}$ of the fertilizers and straws occurs. According to Amarasiri and Wickramasinghe (1988), non-exchangeable K content of soilis a better indicator that indicates the effect of rice straw on $\mathrm{K}$ dynamics in soil and yield components of rice compared to the exchangeable K content.

\section{Dry weight of shoots at $100 \%$ flowering}

As depicted in Figure 01, there was no significant difference $(\mathrm{P}>0.05)$ in dry weight of the shoots among treatments. This reveals that rice straw and fertilizer application had not affected on the dry weight of shoots four weeks after planting. The result is in agreement with Melton and Dufault (1991) who reported that potassium did not significantly influence any of the growth parameters such as shoot and root dry weights.

\section{Plant K content}

The relationships between the optimum potassium content in leaf and stem of rice and different treatments are presented in Figure 02. There was a significant difference in plant $\mathrm{K}$ content among the treatments. $\mathrm{K}$ content in rice plant was significantly higher $(\mathrm{P}<0.05)$ in leaves compared to the stem (Figure 02). Conversely, Slaton et al. (2009) reported the highest K concentration in the stem. This may be due to the fact that rice stems represent the majority of above ground plant biomass and contain 50 to $75 \%$ of the total $\mathrm{K}$. The $\mathrm{K}$ concentrations in mature rice stem are usually $>1.0 \%$ when $\mathrm{K}$ availability is not growth or yield limiting. 
According to the present results, the highest leaf and stem $\mathrm{K}$ contents were recorded (leaf and stem $\mathrm{K}$ contents 0.87 and $0.73 \%$, respectively) in T3 plots (straw + basal $\mathrm{K}+$ panicle initiation $\mathrm{K})$ and the lowest $\mathrm{K}$ content was recorded (leaf and stem $\mathrm{K}$ contents 0.57 and $0.51 \%$, respectively) in the control plots. It can be thus concluded that to maintain optimum $\mathrm{K}$ content in leaf and stem of rice plant, it is needed to apply $\mathrm{K}$ fertilizer as well as rice straw.

The $\mathrm{K}$ fertilizer treated plots depicted higher $\mathrm{K}$ content in leaf and stem of rice compared to the no $\mathrm{K}$ fertilizer treated plots (with or without straw added plots). Therefore, the results imply that the rice straw has not severely affected on the $\mathrm{K}$ content in rice plant. This may be due to the loss of $\mathrm{K}$ in rice straw as a result of submergence in rain water.

Low $\mathrm{K}$ content in plant can be resulted due to some other reasons as well. However, importance of $\mathrm{K}$ in plant has been given elsewhere. According to Ariyaratne (2000), sufficient K (above $1.5 \%$ in leaf dry matter) after flowering is necessary to facilitate carbohydrate translocation, which enhances the grain filling to give an increased 1000 grain weight. On the other hand, when $\mathrm{K}$ nutrition is low, rice is more susceptible to many plant diseases, which can cause yield and/or quality losses. Therefore, it is worthwhile to maintain optimum $\mathrm{K}$ content in the leaf and stem of rice plant (Dobermann and Fairhurst, 2002).

\section{Total K uptake by plants}

There was a significant difference $(\mathrm{P}<0.05)$ between plant $\mathrm{K}$ uptake of different treatments (Figure 03). The highest $\mathrm{K}$ content was recorded in $\mathrm{K}$ fertilizer treated plots and the lowest $\mathrm{K}$ content in the control plots. As a result, higher $\mathrm{K}$ uptake by rice plants was recorded from plots, which were treated with $\mathrm{K}$ fertilizer (basal $\mathrm{K}+$ panicle initiation K) in T6 plots. Parallel to the increase of dry weight of shoots plants (Figure 01 ), the $\mathrm{K}$ uptake into the dry matter was noticeably increased in the plots added with $\mathrm{K}$ fertilizer and rice straw. Availability of high level of $\mathrm{K}$ in the treated plots may be due to two reasons: (i) application of $\mathrm{K}$ fertilizer and (ii) application of rice straw. Initially, the soils had low exchangeable and non-exchangeable $\mathrm{K}$, suggesting the need of applying $\mathrm{K}$ for adequate $\mathrm{K}$ supply to the plants. Potassium fertilization and rice straw application significantly $(\mathrm{P}<0.05)$ increased soil exchangeable and nonexchangeable $\mathrm{K}$ over the control (Table 02 and 03 ). With the increment of soil $\mathrm{K}$ a greater increase in plant $\mathrm{K}$ uptake could be observed.

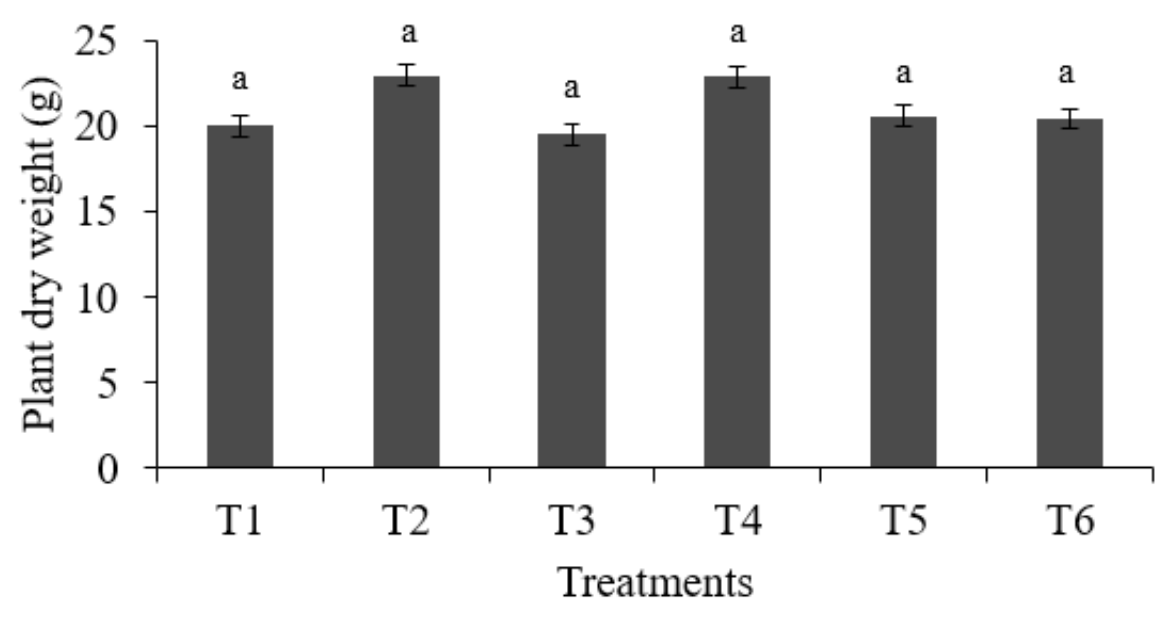

Figure 01: Dry weight of shoots at eight weeks after planting. Means followed by the same letter are not significantly different by Duncans post-hoc test at $P<0.05$. 


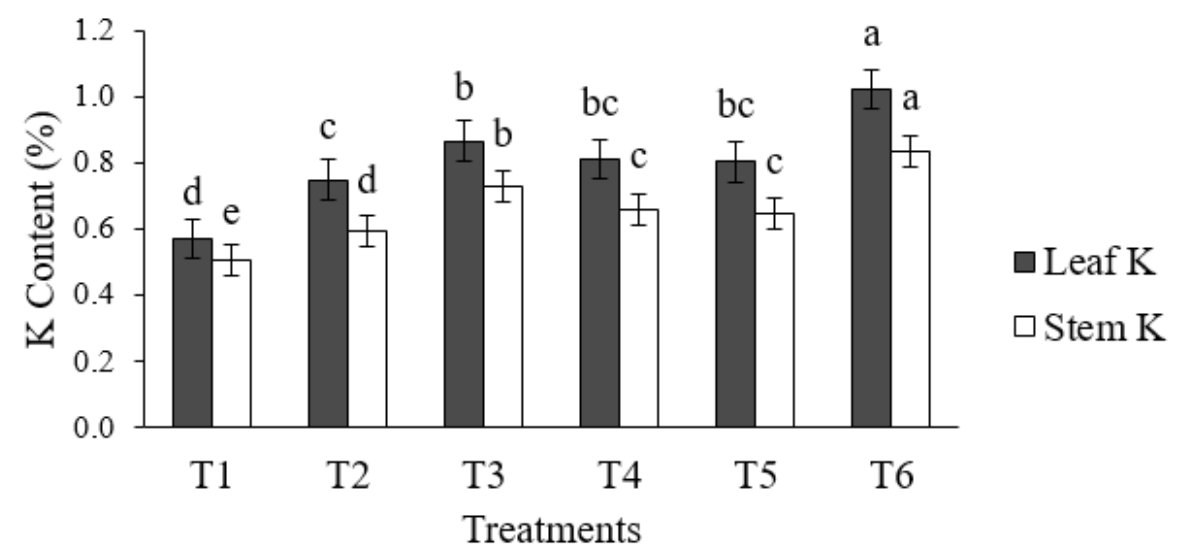

Figure 02: Plant $K$ content. Means followed by the same letter at the same coloured column are not significantly different by Duncans post-hoc test at $\mathbf{P}<0.05$.

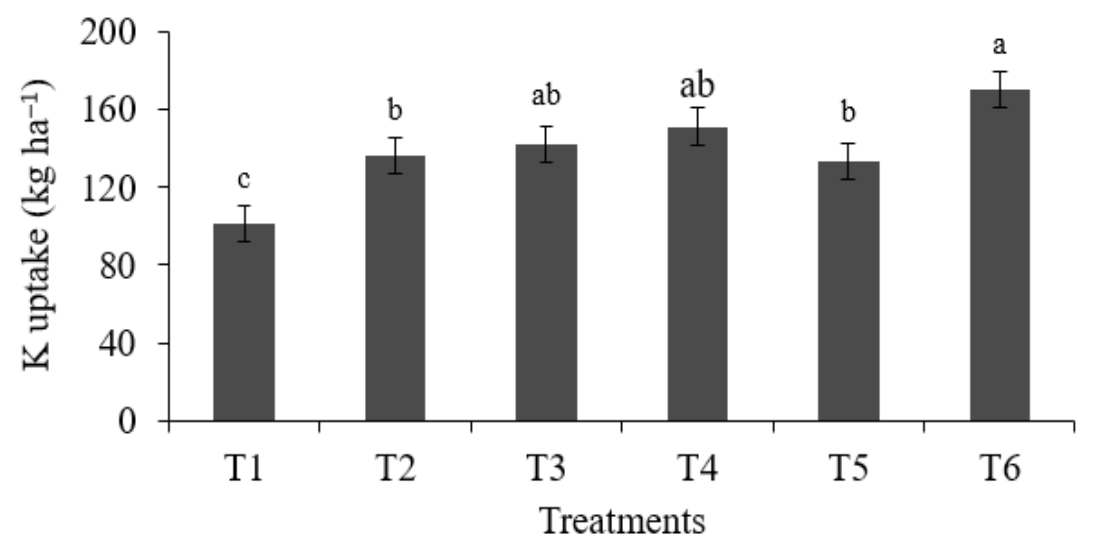

Figure 03: $\mathrm{K}$ uptake by plants $\left(\mathrm{kg} \mathrm{ha}^{-1}\right)$. Means followed by the same letter are not significantly different by Duncans post-hoc test at $\mathrm{P}<0.05$.

\section{Agronomic parameters and grain yield}

As Table 04 shows, there was a significant difference $(\mathrm{P}<0.05)$ in the plant height. The maximum plant height was obtained in the plots, which were treated with $\mathrm{K}$ fertilizer and straw. The lowest was observed in the unamended control. Nevertheless, there was no significant difference $(\mathrm{P}>0.05)$ in the number of tillers per hill.

The maximum number of panicles per hill was obtained in T3 (Table 04). Findings of Dobermann and Fairhurst (2000) are also in agreement with the present results. According to their findings, $\mathrm{K}$ increases the number of spikelets per panicle and grain yield.

As given in Table 04, there was a significant difference $(\mathrm{P}<0.05)$ in grain yield among the treatments. This shows that rice straw had a very similar capacity to that of MOP in increasing the yield in paddy cultivation. The factors that may have contributed to a significantly higher $(\mathrm{P}<0.05)$ yield are number of panicles per hill and the higher biomass production with increased availability of K in T3. Moreover, the maximum grain yield was recorded in the plots of $\mathrm{T} 3$, which contained straw and $\mathrm{K}$ fertilizer while the lowest was recorded in the control plots, which were not treated with $\mathrm{K}$ fertilizer. 
Table 04: Mean number of tillers, plant height, number of panicles and grain yield as affected by rice straw and $\mathrm{K}$ fertilizer treatments.

\begin{tabular}{ccccc}
\hline & \multicolumn{2}{c}{ At maximum tillering stage } & \multicolumn{2}{c}{ At harvesting stage } \\
\hline Treatments & Plant height $(\mathrm{cm})$ & No of tillers & $\begin{array}{c}\text { Number of panicles } \\
\text { per hill }\end{array}$ & $\begin{array}{c}\text { Grain yield (kg/ } \\
\text { hill) }\end{array}$ \\
\hline T1 & $92.3^{\mathrm{b}}$ & $10.0^{\mathrm{a}}$ & $6.80^{\mathrm{a}}$ & $7.5^{\mathrm{c}}$ \\
T2 & $95.4^{\mathrm{ab}}$ & $10.0^{\mathrm{a}}$ & $6.70^{\mathrm{a}}$ & $7.6^{\mathrm{bc}}$ \\
T3 & $97.8^{\mathrm{ab}}$ & $11.0^{\mathrm{a}}$ & $7.20^{\mathrm{a}}$ & $8.3^{\mathrm{a}}$ \\
T4 & $98.5^{\mathrm{a}}$ & $11.0^{\mathrm{a}}$ & $6.75^{\mathrm{a}}$ & $7.9^{\mathrm{abc}}$ \\
T5 & $99.6^{\mathrm{a}}$ & $9.0^{\mathrm{a}}$ & $6.50^{\mathrm{a}}$ & $8.1^{\mathrm{ab}}$ \\
T6 & $95.8^{\mathrm{ab}}$ & $11.0^{\mathrm{a}}$ & $6.70^{\mathrm{a}}$ & $7.9^{\mathrm{abc}}$ \\
\hline
\end{tabular}

Means followed by the same letter at the same column are not significantly different by Duncans post-hoc test at $\mathrm{P}<0.05$.

\section{CONCLUSIONS}

According to the results, there was a positive relationship between exchangeable $\mathrm{K}$ and non-exchangeable $\mathrm{K}$ with increasing level of $\mathrm{K}$ in soil. Though exchangeable and nonexchangeable $\mathrm{K}$ contents in all six treatments were significantly low $(\mathrm{P}<0.05)$ at planting and harvesting, application of rice straw and $\mathrm{K}$ fertilizer increased the soil exchangeable $\mathrm{K}$ content and non- exchangeable $\mathrm{K}$ content. Rice straw maintains the exchangeable $\mathrm{K}$ content and as well as the non-exchangeable $\mathrm{K}$ pools in paddy fields in the initial stage.
Significant differences in total grain yield and $\mathrm{K}$ concentration of plant parts among treatments were observed. With an increased level of soil exchangeable $\mathrm{K}$, non-exchangeable $\mathrm{K}$ contents, dry weight of shoots and plant $\mathrm{K}$ uptake increased. When plant $\mathrm{K}$ uptake in relation to the non-exchangeable $\mathrm{K}$ is considered there was a positive relationship irrespective of the treatments applied and a number of weeks after planting. Though chemical $\mathrm{K}$ fertilizer is an important $\mathrm{K}$ source for paddy cultivation, rice straw plays a significant role in maintaining soil $\mathrm{K}$ as well as plant $\mathrm{K}$ content.

\section{REFERENCES}

Amarasiri, S.L., and Wickremasinghe, K. (1988). Nitrogen and potassium applied to flooded rice by recycling rice straw. Tropical Agriculturist.144:23-34.

Anon, (1956). Plant potassium analysis. Analytical Methods Committee - Analyst, London, England.

Ariyaratne, R.M. (2000). Integrated Plant Nutrient Systems (IPNS), Training Manual, National Fertilizer Secretariat and Ministry of Agriculture and Livestock Development, Colombo. Report No. FADINAP/PRUDD/RDS/CAP/00/046-B. Retrieved on: July, 02nd 2014, Available at: http://www.fadinap.org/ipns/srilanka/ipnsmanual/toc.hlml.

Bandara, W.M.J., Wickramasinghe, W.M.A.D.B.,Sirisena, D.N. and Wijewardana, J.D.H (2009). Response of rice to applied potassium in soils of Sri Lanka. In: Use of phosphorus and potassium fertilizers in SriLankanagriculture.(Kumaragamage, D.,Satyanarayana, T.,Singh, H. and Majumdar, K. Eds.). International Plant Nutrition Institute (IPNI), Gurgaon, Haryana, India. 89-117. 
Department of Agriculture, (2010). Crop Recommendations of the Department of Agriculture, Sri Lanka.

Dobermann, A. and Fairhurst, T.H. (2000). Rice: Nutrient disorders and nutrient management in rice. International Rice Research Institute and Potash and Phosphate Institute of Canada $72-83$.

Dobermann, A. and Fairhurst, T.H. (2002). Rice Straw Management, Better Crops International, Volume 16, Special Supplement, May 2002.

Food and Agriculture Organization of the United Nations,(2004). Rice and narrowing the yield gap. Accessed at http://www.fao.org/ rice2004/en/f-sheet/factsheet5.pdf

Liyanage, N.J., Keerthisinghe, G.,Jayakody, A.N. and Thenabandu, M.W. (1989). Changes of potassium reserves in an Alfisolunder irrigated paddy at different phosphorus and nitrogen levels. In: Tropical Agriculture Research. Volume1. (Bandara, J.M.R.S. Ed.) Post Graduate Institute of Agriculture, University of Peradeniya, Sri Lanka.285 - 297.

Mapa, R.B., Nagarajah, S. and Somasiri, S. (2005). Soils of the Intermediate Zone of Sri Lanka: Morphology, Characterization and Classification. Special Publication No.1, Soil Science Society of Sri Lanka.

Melton, R.R. and Dufault,R.J. (1991). Nitrogen, phosphorus, and potassium fertility regimes affect tomato transplant growth. Horticultural Science. 26(2): 141-142.

Palm, C.A., Myers, R.J.K. and Nandwa, S.M. (1997). Combined use of organic and inorganic nutrient sources for soil fertility maintenance and replenishment. In: Replenishing soil fertility in Africa. (Buresh, R.J., Sanchez, P.A. and Calhoun, E. Eds.).Soil Science Society of America: Madison, Wisconsin, 193-217.

Panabokke, C.R. and Nagarajah, S. (1964): The fertility characteristics of rice growing soils of Ceylon. Tropical Agriculturist. 120: 3-30.

Perkin-Elmer. (1994). Analytical Methods for Atomic Absorption Spectroscopy. The Perkin-Elmer Corporation, USA. $1-310$.

Pratt, P.F. (1965). Potassium. In: Methods of Soil Analysis, Part 2: Chemical and Microbial Properties. (Black, C.A. Ed.). American Society of Agronomy, Madison, Wisconsin. 10231031.

Reitemeier, R.F. (1951). The chemistry of soil potassium. Advances in Agronomy. 3: 113 - 164. https:/doi.org/10.1016/S0065-2113(08)60368-5

Sirisena, D.N., Wickramasinghe, D.B. and Silva, L.S. (2001). Recovery of fertilizer N applied to wetland paddy soils. Annals of Sri Lanka, Department of Agriculture. 3:231 - 236.

Slaton, N. A., Golden, B.R.,Norman, R.J.,Wilson, Jr., C.E. and DeLong, R.E. (2009). Correlation and calibration of soil potassium availability with rice yield and nutritional status. Journal of Soil Science Societyof America. 73:1192 - 1201. https:/doi.org/10.2136/sssaj2008.0200 
Sparks, D.L. and Huang, P.M. (1985). Physical chemistry of soil potassium. In: Potassium in agriculture. (Munson, R.D. Ed.). American Society of Agronomy, Madison, Wisconsin. 201 -276 .

Weerasinghe, P. (1991). Response of irrigated lowland rice to addition of N, P and K fertilizers in Non-Calcic Brown Soils. Tropical Agriculturist. 147: 75-84. 